\title{
TINDAK TUTUR MEMINTA OLEH PEMBELAJAR BIPA DARI KOREA: KAJIAN PRAGMATIK BAHASA ANTARA (INTERLANGUAGE PRAGMATICS)
}

\author{
Adista Nur Primantari ${ }^{1}$ \\ Prof. Dr. I Dewa Putu Wijana, S.U., M.A. ${ }^{2}$ \\ ${ }^{1}$ Pusat Pengembangan Strategi dan Diplomasi Kebahasaan \\ Badan Pengembangan dan Pembinaan Bahasa \\ Kementerian Pendidikan dan Kebudayaan \\ Email: dista_np@yahoo.com \\ ${ }^{2}$ Fakultas Ilmu Budaya - Universitas Gadjah Mada \\ Email: idp_wijana@yahoo.com
}

\begin{abstract}
This study is aimed at explaining what causes the differences occurred in Indonesian request utterances produced by Korean learners of Indonesian. The data used in this research were taken directly from the fieldwork. The data were taken through direct observation by recording and taking notes from conversations between Korean people living in Yogyakarta whostudies Indonesian language. To collect the data, the researcher distributed questionnaires. After collecting the data, the researcher analyzed them in the area of pragmatics, compared the data between the Korean and Indonesian speakers, and discussed the factors causing the differences. The researcher reveals that the Korean learning Indonesian produce different request utterance forms compared to the native speakers. The factors of request utterance differences used by Korean learning Indonesian are mainly caused by linguistics and non-linguistics factors. The linguistics factors are the impact of Korean pragmatics knowledge transfer and the imperfection of grammatical knowledge meanwhile the non-linguistics factors are cultural differences, intake of Indonesian learning, and habit of using informal forms in daily conversation.
\end{abstract}

Keywords: Interlanguage Pragmatics, Pragmatics System, Cultural Differences, Bahasa Indonesia, Indonesian learners from Korea

\begin{abstract}
ABSTRAK
Kajian ini bertujuan untuk menjelaskan factor-faktor yang menyebabkan perbedaan dalam kemunculan tuturan meminta dalam bahasa Indonesia yang diproduksi oleh pembelajar BIPA dari Korea. Data dalam penelitian ini diambil secara langsung dari lapangan dengan cara merekam dan menyebar kuesioner bagi para pembelajar BIPA dari Korea di Yogyakarta. Setelah data terkumpul, data tersebut dianalisis dengan perspektif pragmatic untuk memperoleh faktor-faktor yang berpengaruh terhadap perbedaan tuturan meminta yang diproduksi oleh pembelajar BIPA dari Korea. Kajian ini merupakan kajian lanjutan dari penelitian sebelumnya yang mengkaji perbedaan bentuk tuturam. Fokus kajian ini adalah pada faktor-faktor yang mempengaruhi kemunculan tuturan tersebut. Faktor utama kemunculan perbedaan tuturan ini
\end{abstract}


adalah karena faktor linguistik dan faktor nonlinguistic. Faktor linguistik mencakup pengaruh bahasa antara dan kekurangsempurnaan peenguasaan tata bahasa Indonesia oleh pembelajar BIPA dari Korea. Sementara itu, faktor nonlinguistic utamanya disebabkan karena perbedaan budaya antara orang Indonesia dan orang Korea, saat dimulainya mempelajari bahasa Indonesia, dan kebiasaan orang Korea dalam menggunaakan ragam bahasa Indonesia yang informal.

Kata kunci: Interlanguage Pragmatics, Pragmatics System, Cultural Differences, Bahasa Indonesia, Indonesian learners from Korea

\section{PENDAHULUAN}

Tindak tutur meminta dikategorikan sebagai tindakan yang kemungkinan akan mengancam 'muka' lawan tutur atau face-threatening acts (FTAs) (Brown dan Levinson, 1987). Bentuk-bentuk tuturan yang berbeda banyak ditemukan dalam tuturan meminta yang diproduksi oleh pembelajar BIPA dari Korea (PBK) ketika menggunakan bahasa Indonesia. Sebagian besar dari perbedaan tersebut menyebabkan tuturannya tidak mematuhi kesantunan dalam bahasa Indonesia. Tidak dapat dipungkiri bahwa bentuk-bentuk yang berbeda tersebut terbentuk karena kemampuan gramatikal PBK belum memadai. Akan tetapi, adanya transfer negatif dari sistem pragmatik bahasa Korea, interferensi budaya Korea, dan beberapa faktor nonlinguistik, seperti lingkungan pembelajaran bahasa Indonesia, pergaulan, dan kebiasaan ikut berperan sebagai faktor yang menyebabkan perbedaan bentuk tuturan meminta yang dihasilkan oleh PBK. Menurut latar belakang di atas, permasalahan dalam penelitian ini adalah sebagai berikut. Bagaimana perbedaan bentuk tuturan meminta dalam bahasa Indonesia yang dihasilkan oleh pembelajar BIPA dari Korea dan oleh penutur asli serta faktor-faktor apa saja yang menyebabkan perbedaan tersebut?

Tanaka (1988) dalam Nadar (2009:99) melakukan penelitian kontrastif tentang kesantunan berbahasa orang-orang Jepang yang mampu berbicara bahasa Inggris. Dengan menggunakan teori Brown dan Levinson (1978), kesantunan berbahasa orang Jepang dibandingkan dengan warga Australia. Hasil penelitian ini menunjukkan bahwa dibandingkan mahasiswa Australia, mahasiswa Jepang cenderung menggunakan strategi kesantunan tertentu yang tidak variatif dan kaya sebagaimana yang digunakan oleh mahasiswa Australia. Mahasiswa Jepang juga cenderung tidak memanggil mitra tutur, kurang eksplisit membuat tuturan permintaan, dan cenderung berbicara secara lebih formal.

Kemampuan mahasiswa asing yang belajar bahasa Indonesia juga diteliti oleh Zubaidi (2013) yang mengadakan penelitian tentang "Realisasi Keluhan oleh Pembelajar Asing Bahasa Indonesia: Kajian Pragmatik Bahasa Antara (Interlanguage Pragmatics)". Penelitian ini menyatakan bahwa strategi keluhan yang dipilih mahasiswa Amerika dalam mengeluh dalam bahasa Indonesia, meliputi (1) isyarat, (2) tuduhan langsung, (3) tuduhan tidak langsung, (4) konsekuensi buruk, (5) hukuman eksplisit terhadap pihak yang mendapatkan keluhan, (6) hukuman eksplisit terhadap pihak yang mendapatkan keluhan sebagai persona, (7) celaan termodifikasi, dan (8) kejengkelan. Selain itu, pemilihan strategi keluhan juga dikaitkan dengan faktor sosial yang melatarbelakangi penutur dan konteks tuturan.

Dalam penelitiannya yang berfokus pada keluhan yang diproduksi oleh pembelajar bahasa Inggris dari Korea, Park (2001) membuktikan bahwa faktor budaya berpengaruh terhadap pemilihan tuturan. Hasil penelitian menunjukkan bahwa pembelajar menampilkan transfer pragmatik dari bahasa Korea ke dalam bahasa Inggris. Hal ini sesuai dengan penelitian 
Sukamto (2012) yang melakukan penelitian mengenai cara yang dilakukan orang Korea untuk memproduksi tuturan santun dalam bahasa Indonesia. Penelitian ini merupakan penelitian lintas budaya yang membandingkan bagaimana perbedaan strategi orang Korea dan orang Indonesia dalam melakukan tindak tutur. Penelitian tersebut lebih berfokus pada bidang pragmatik antarbudaya daripada pragmatik bahasa antara.

Berdasarkan fakta tersebut, penelitian ini menarik dilakukan untuk mengetahui faktor yang mempengaruhi kemunculan erbedaan tersebut, baik linguistik maupun faktorfaktor nonlinguistik, seperti perbedaan budaya, pola pergaulan, kebiasaan, dan lingkungan pembelajaran. Sampai saat ini, analisis permasalahan yang sama dengan apa yang ada dalam penelitian ini belum ada dan memadai. Kalaupun sudah ada penelitian yang mirip, diharapkan pembahasan masalah ini dapat menjadi pelengkap terhadap hasil penelitian yang lain.

Penelitian initermasuk dalam studi pragmatik bahasa antara. Pada umumnya, studi mengenai bahasa antara berkaitan dengan kemampuan pembelajar bahasa kedua dalam menggunakan kemampuan pada ranah fonologi, morfologi, dan sintaksis. Akan tetapi, kemudian mucul bidang baru yang disebut pragmatik bahasa antara, yaitu suatu bidang yang menggabungkan studi mengenai pembelajaran bahasa kedua dengan studi pragmatik. Pragmatik bahasa antara adalah sebuah studi mengenai bagaimana pembelajar bahasa kedua menggunakan kemampuan pragmatik dan pemahaman wacananya untuk berkomunikasi pada bahasa kedua. Studi tentang budaya cara bertutur yang berbeda disebut pragmatik kontrastif. Secara lebih lanjut, studi kontrastif ini dilakukan dalam pragmatik lintas budaya yang menjelaskan perbedaan-perbedaan cara bertutur berdasarkan perbedaan budaya. Akan tetapi, jika penelitian kontrastif tersebut difokuskan secara lebih khusus pada tingkah laku komunikatif dari orang yang bukan penutur asli saat berkomunikasi dalam bahasa kedua dan membandingkannya dengan tingkah laku komunikatif penutur asli, penelitian tersebut dideskripsikan sebagai pragmatik bahasa antara (Yule, 1996: 151).

Studi pragmatik bahasa antara berkaitan dengan performansi dan pemerolehan kemampuan pragmatik dalam pembelajaran bahasa kedua. Oleh karena berkaitan dengan dua bahasa yang berbeda, studi ini juga berkaitan dengan pola linguistik dan pola budaya yang berbeda pula. Sejumlah kajian pragmatik bahasa antara telah diterapkan pada berbagai bahasa, baik itu berupa studi sinkronis atau perkembangan. Istilah bahasa antara atau interlanguage pertama kali digunakan oleh Selinker pada tahun 1969. Dalam proses pembelajaran bahasa kedua atau bahasa asing, pembelajar akan mengalami tahapan proses psikolinguistik sebelum mereka memperoleh bahasa keduanya. Performansi pembelajar yang belum sempurna dan belum mencapai kompetensi dalam bahasa sasaran akan ditandai dengan adanya bentukbentuk yang menyimpang dari kaidah bahasa target. Tahapan itu disebut interlanguage atau interlingual. Interlingual bersifat independen, yaitu tidak berkaitan dengan bahasa pertama dan juga tidak berkaitan dengan bahasa kedua walaupun kadangkala memperlihatkan pengaruh dari keduanya. Ketika si terdidik mentransformasi dan menghasilkan pola-pola bahasa akibat aktivitas belajarnya, pengaruh dari bahasa pertama selalu muncul. Aktivitas belajar yang menghasilkan pola-pola pada bahasa kedua yang dipengaruhi oleh bahasa pertama disebut interlingual (Selinker dalam Pateda, 1989:73).

Penelitian pragmatik bahasa antara ini memilih menggunakan tindak tutur meminta untuk menguji kemampuan bahasa Indonesia pembelajar bahasa Indonesia dari Korea. Ada beberapa alasan mengapa penelitian ini memfokuskan analisis penyimpangan interlingual pada tindak tutur meminta. Pertama, permintaan adalah tindak tutur yang sangat berguna dan sering terjadi dalam komunikasi, khususnya bagi pembelajar bahasa asing. Kedua, dibandingkan dengan tindak tutur yang lain, tindak tutur meminta adalah salah satu jenis tindak tutur yang paling banyak dipelajari di dalam pembelajaran bahasa asing. Ketiga, tindak tutur meminta 
yang dinyatakan dalam konteks-konteks tertentu dapat digunakan untuk menginvestigasi perkembangan kemampuan pragmatik pembelajar (Achiba, 2003).

Perbedaan-perbedaan bentuk tuturan meminta yang dihasilkan oleh pembelajar dan penutur asli tersebut dapat terlihat dari bentuk tuturan yang dihasilkan. Pada umumnya, perbedaan terletak pada pemilihan strategi meminta dan elemen-elemen yang digunakan untuk menyusun tuturan permintaan. Perbedaan ini berkaitan dengan budaya asli dan transfer negatif dari B1 pembelajar. Jika tidak diperhatikan penggunaannya, perbedaan tersebut dapat mengancam muka penutur dan melanggar kesantunan dalam bahasa Indonesia. Oleh karena itu, penelitian ini dikaitkan juga dengan teori mengenai kesantunan lintas budaya.

Dasar dari teori kesantunan lintas budaya adalah teori kesantunan berbahasa. Teori kesantunan berbahasa yang banyak diacu saat ini adalah yang dikemukakan oleh Brown dan Levinson (1978) dan Leech (1993). Brown dan Levinson (1978:61) mengemukakan bahwa face 'muka' adalah hal yang mendasar dalam teori strategi kesantunan berbahasa. Ada dua tipe muka, yaitu muka positif dan muka negatif. Muka negatif adalah keinginan penutur agar setiap keinginannya tidak dihalangi oleh pihak lain sedangkan muka positif adalah keinginan setiap penutur agar dia dapat diterima dan disenangi oleh pihak lain. Konsep tentang muka ini bersifat universal dan secara alamiah dalam setiap bahasa ditemukan banyak tuturan yang cenderung merupakan tindakan yang tidak menyenangkan yang disebut Face Threatening Acts 'tindakan yang mengancam muka' dan biasanya disingkat menjadi FTA.

Pembelajaran bahasa kedua memunculkan permasalahan ketika pembelajar bentukbentuk B2 yang dipengaruhi B1. Hal yang dipengaruhi bukan hanya segi strukturalnya, tetapi juga sistem budayanya. Hal ini terlihat pada tuturan-tuturn meminta bahasa Indonesia yang dihasilkan oleh pembelajar BIPA dari Korea. Ada banyak tuturan yang berbeda dari penutur asli dan hal tersebut dipengaruhi oleh sistem pragmatik B1 dan perbedaan budaya.

\section{HASIL DAN PEMBAHASAN}

Bentuk-bentuk tuturan meminta (TTM) yang berbeda yang dihasilkan oleh PBK dibedakan menjadi empat bagian besar, yaitu perbedaan dalam pemilihan ragam formal dan informal, perbedaan dalam pemilihan strategi tutur, perbedaan dalam pemilihan formula semantik, dan perbedaan dalam pemilihan pronomina persona.

\section{a. Perbedaan dalam Pemilihan Ragam Formal dan Informal}

Ada beberapa data yang menunjukkan bahwa PBK belum dapat memilih ragam yang tepat untuk merealisasikan permintaan sesuai situasi dan kedudukan mitra tuturnya. Saat situasi menuntut dipilihnya ragam informal, PBK memilih menggunakan ragam formal seperti terlihat pada data (37) dan (38). Sebaliknya, saat situasi menuntut dipilihnya ragam formal, PBK memilih menggunakan ragam informal seperti dapat dilihat pada data (39) dan (40).

\section{PBK}

(37) Halo. Nama saya Yumi yang sedang belajar di jurusan bahasa Indonesia. Anda juga belajar di jurusan bahasa Indonesia, kan? Saya pernah melihat Anda di kelas matakuliah. Boleh Anda meminjamkan pen?

Konteks: PBK meminjam pena kepada adik kelas.

\section{Penutur Asli}

(38) Dik, bawa pena berapa? Boleh saya pinjam?

Konteks: Penutur asli meminjam pena kepada adik kelas. 
(39) Pak, aku berminat sekali kuliah pak. Pak (40) Bapak, maaf saya ingin ikut kelas Bapak, adalah salah satu prof yang paling bagus di tapi sudah penuh. Apakah kira-kira Bapak bisa dunia ini. Aku boleh ikut nggak? Cuma 'sit-in' menambah satu lagi untuk saya? Karena saya aja. benar-benar butuh kuliah ini.

Konteks: PBK meminta izin kepada profesor Konteks: Penutur asli meminta izin kepada untuk dapat mengikuti kuliah beliau yang profesor untuk dapat mengikuti kuliah beliau sudah memenuhi kuota. yang sudah memenuhi kuota.

\section{b. Perbedaan dalam Pemilihan Strategi Tutur}

Secara umum, PBK sudah dapat menggunakan beberapa variasi strategi yang santun saat menghasilkan tuturan meminta dalam bahasa Indonesia. Modus kalimatnya bervariasi, mulai dari kalimat imperatif, kalimat interogatif, kalimat deklaratif hingga kalimat eksklamatif. Untuk membuat tuturan mereka tetap santun, PBK paling banyak menggunakan kalimat bermodus interogatif dan deklaratif. Kalimat bermodus imperatif banyak dihindari dalam beberapa situasi dikarenakan PBK dapat memahami penggunaan kalimat tersebut tidak santun karena tipe tuturannya langsung. Selain itu, hanya ada beberapa tuturan yang menggunakan tuturan bermodus eksklamatif.

Di atas sudah dijelaskan bahwa PBK dapat menuturkan permintaan dalam 16 cara. Akan tetapi, penutur asli bahasa Indonesia memiliki cara yang lebih banyak. Ada lima cara meminta yang tidak dikuasai oleh PBK dan hanya ditemukan dalam data tuturan meminta penutur asli. Cara lain tersebut adalah (1) menggunakan bentuk pasif, (2) melekatkan partikel -kah, (3) melekatkan imbuhan meN- pada kata kerja, (4) menggunakan pengandaian, (5) memuji. Jika dijumlahkan dengan cara-cara sama yang diproduksi oleh PBK, ada 21 cara meminta yang digunakan penutur asli.

Imbuhan $m e N$ - yang dilekatkan pada kata kerja membuat tuturan permintaan menjadi lebih santun. Strategi ini berkaitan dengan ragam kalimat. Pelekatan imbuhan $m e N$ - mengakibatkan tuturan yang dihasilkan menjadi ragam formal. Hal ini dapat dijelaskan karena penggunaan kata kerja dasar yang berkaitan dengan bentuk tidak baku dapat dihindari. Berikut ini adalah beberapa tuturan yang dapat menggambarkan perbedaan penggunaan strategi ini oleh PBK dan penutur asli bahasa Indonesia.

\section{PBK}

Penutur Asli

(41) Prof, kakakku menikah jadi aku nggak (43) Selamat siang, Prof. Saya bermaksud bisa ikut ujian. Boleh gantikan dengan tugas? menyampaikan bahwa minggu depan saya tidak dapat mengikuti kuliah Bahasa

Konteks: Anda meminta ujian susulan kepada Indonesia karena kakak saya melangsungkan profesor yang Anda kenal dengan baik karena pernikahan di hari yang sama. Apakah saya kakak Anda menikah bertepatan dengan hari boleh mengikuti ujian susulan, Prof? ujian Anda. 
(42) Guru, saya Jujang dari Korea. Saya mau sit in di kuliah guru. Minta beri surat izinnya. Minta tolong!

Konteks: Anda meminta izin kepada profesor untuk dapat mengikuti kuliah beliau yang sudah memenuhi kuota.
(44) Bapak, mohon maaf sebelumnya. Saya ingin meminta izin pada hari Kamis tanggal 23 kakak saya menikah dan bertepatan dengan hari ujian. Bolehkah saya mengerjakan soal ujian tersebut di hari lain?

Konteks: Anda meminta izin kepada profesor untuk dapat mengikuti kuliah beliau yang sudah memenuhi kuota.

Keempat data di atas menampilkan adanya perbedaan dalam pemilihan kata kerja yang digunakan dalam tuturan. PBK cenderung memilih kata kerja berupa kata kerja dasar tanpa adanya pelekatan imbuhan. Sementara itu, penutur asli bahasa Indonesia melekatkan imbuhan $m e N$ - pada kata kerja dan tidak menggunakan kata dasar dalam tuturan permintaannya. Strategi pelekatan imbuhan $m e N$ - ini berfungsi untuk memperhalus tuturan permintaan dan menaikkan derajat kesantunan. Kata kerja yang berimbuhan $m e N$ - dipandang lebih santun daripada kata kerja dasar. Hal ini berkaitan dengan pemilihan ragam. Kata kerja berimbuhan membuat ragam tuturan menjadi formal dan ragam formal ini memiliki derajat kesantunan yang tinggi.

\section{c. Perbedaan dalam Pemilihan Formula Semantik}

Formula semantik adalah elemen-elemen penyusun tuturan permintaan. Elemen-elemen ini memiliki fungsi untuk mendukung dan melancarkan maksud permintaan yang dituturkan. Ada perbedaan dalam pemilihan formula semantik yang digunakan oleh PBK dan penutur asli untuk menyusun tuturan permintaan. Perbedaan dalam penggunaan formula semantik ini ditemukan pada pemilihan kata sapaan, pemilihan kata penanda kesantunan, pemilihan kata penarik perhatian, dan pemilihan kata perkenalan.

\section{1) Pemilihan Kata Sapaan}

Dalam menuturkan permintaan dalam bahasa Indonesia, PBK memilih beberapa kata sapaan yang berbeda dengan kata sapaan yang lazimnya dipilih oleh penutur asli bahasa Indonesia. Perbedaan itu terlihat dari pemilihan kata untuk memanggil nama mitra tutur atau menyapa mitra tutur.

PBK lebih banyak memilih kata sapaan yang merujuk pada jabatan dan gelar keilmuan daripada penutur asli. Untuk menyapa mitra tuturnya, PBK menggunakan kata sapaan Profesor, Prof, Guru, dan Dosen sedangkan penutur asli tidak menggunakan kata Guru dan Dosen untuk menyapa. Penutur asli lebih banyak menggunakan pilihan kata sapaan berupa hubungan kekerabatan. Pemilihan kata sapaan jenis ini oleh penutur asli juga lebih bervariasi, yaitu Bapak, Pak, Ibu, Bu, Adik, Dik, Dek, Mas, dan Mbak. Berikut ini adalah tuturan yang menggambarkan hal tersebut.

\section{PBK}

Penutur Asli

(45) Profesor, saya Yumi dari Korea. Saya (48) Maaf, Bapak. Begini, saya berencana mau meminta surat izin untuk ikut kuliah mengajukan beasiswa dan bermaksud Profesor yang menarik. Minta tolong. meminta surat rekomendasi dari Bapak jika Bapak berkenan. 
(46) Guru, saya Jujang dari Korea. Saya mau (49) Maaf, Mas, Jalan Kaliurang KM 5 di sit in di kuliah Guru. Minta beri surat izinnya. mana, ya?

Minta tolong.

(47) Maaf, Dosen. Saya masih belum (50) Dik, maaf punya nomor hape Pak Bowo selesaikan tugas, kalau boleh minta tambah nggak?

waktu, Pak.

Untuk menyapa dosennya, penutur asli lebih suka menggunakan kata sapaan berupa hubungan kekerabatan seperti Bapak dan Ibu sedangkan PBK menyapa dengan jabatan atau gelar keilmuan, seperti Profesor, Guru, dan Dosen. Ditemukan juga data tuturan permintaan oleh PBK yang menggunakan pilihan kata sapaan Mas dan Mbak, tetapi hanya dalam jumlah yang kecil dan tidak sebanyak yang digunakan oleh penutur asli.

Selain itu, PBK juga menggunakan sapaan yang tidak lazim digunakan untuk menyapa mitra tutur yang tidak dikenal dalam bahasa Indonesia, yaitu Paman seperti terlihat dalam data berikut ini.

(51) Permisi, Paman. Numpang tanya. Saya sekarang mau ke nomor ini, tetapi saya sekarang bingung harus kemana.

(52) Permisi Paman, boleh saya tanya? kalau saya ke jalan X, bagaimana ya?

Konteks: PBK meminta informasi letak kos teman kepada orang tak dikenal yang ditemui di jalan.

Sapaan Paman ditemukan pada situasi PBK meminta informasi letak suatu alamat pada orang yang tak dikenal di jalan. Walaupun sama-sama memiliki jarak familiaritas yang rendah, PBK tidak menggunakan kata sapaan Paman ini untuk menyapa dosennya. Hal ini berkaitan dengan sistem sapaan dalam bahasa Korea. Dalam bahasa Korea, kata kekerabatan Paman (ajeossi, 아저씨) dan Bibi (ajumma, 아주마) digunakan untuk menyapa mitra tutur yang tingkat familiaritas yang rendah dan memiliki status sosial yang lebih tinggi daripada penutur. Akan tetapi, sapaan ini biasanya juga digunakan untuk menyapa penjual makanan atau orang tak dikenal di jalan yang terlihat lebih tua usianya. Sementara itu, untuk menyapa penjual makanan atau orang yang tak dikenal di jalan, orang Indonesia menyapa dengan pilihan kata kekerabatan Bapak atau Ibu. Dengan penjelasan ini, terlihat bahwa PBK masih menerima transfer negatif dari sistem sapaan bahasa Korea saat memproduksi tuturan meminta dalam bahasa Indonesia.

2) Pemilihan Kata Penanda Kesantunan

Ungkapan-ungkapan penanda kesantunan yang dimunculkan oleh PBK untuk melakukan permintaan dalam bahasa Indonesia adalah minta + kata lain, tolong, minta tolong, maaf, minta maaf, permisi, boleh, bisa, mari, dan ayo. Berikut ini adalah perbedaan penggunaan kata penanda kesantunan dalam tuturan meminta PBK dan penutur asli.

PBK

Minta+kata lain

Tolong

Minta tolong

$--$

Maaf

Minta maaf

\section{Penutur Asli}

Tolong

Minta tolong

Mohon

Maaf

Minta maaf 


$\begin{array}{ll}\text { Permisi } & \text { Mohon maaf } \\ \text { Boleh } & \text { Permisi } \\ \text { Bisa } & \text { Boleh(kah) } \\ -- & \text { Bisa(kah) } \\ -- & \text { Bersedia(kah) } \\ \text { Mari } & \text { Berkenan(kah) } \\ \text { Ayo } & \text { Mari } \\ -- & \text { Ayo } \\ \end{array}$

Daftar di atas menunjukkan bahwa penutur asli bahasa Indonesia menggunakan kata penanda kesantunan yang lebih banyak dan lebih bervariasi dalam tuturan permintaannya dibandingkan oleh kata penanda kesantunan yang digunakan oleh PBK. PBK tidak memilih menggunakan kata mohon, kata tanya bersedia(kah), dan berkenan(kah). Selain itu, PBK tidak melekatkan partikel - kah pada kata tanya penanda kesantunan boleh dan bisa. Hal ini berkaitan dengan pemilihan strategi yang telah dianalisis pada bagian sebelumnya. Telah dirumuskan bahwa PBK tidak menggunakan cara melekatkan partikel -kah dalam strategi memintanya seperti halnya yang dilakukan oleh penutur asli. Sementara itu, penutur asli meningkatkan derajat kesantunan tuturannya dengan melekatkan partikel $-k a h$ tersebut pada kata penanda kesantunan boleh, bisa, bersedia, dan berkenan sehingga menjadi terbentuk kata bolehkah, bisakah, bersediakah, dan berkenankah.

PBK sudah dapat menggunakan beberapa ungkapan penanda kesantunan dengan tepat untuk membuat tuturan mereka menjadi santun. Akan tetapi, ada kemunculan satu kata yang mendominasi, yaitu kemunculan kata minta. PBK memunculkan kata minta pada sebagian besar konteks tuturan. Bentuk ini tidak lazim digunakan dalam tuturan meminta dalam bahasa Indonesia karena PBK mengombinasikan bentuk ini dengan kata lain seperti di bawah ini.

$\begin{array}{ll}\text { Minta+Kata Lain } & \text { Contoh } \\ \text { Minta+Penanda Kesantunan } & \text { Minta maaf } \\ \text { Minta+Kata Kerja Intransitif } & \text { Minta pergi } \\ \text { Minta+Kata Kerja Transitif } & \text { Minta antar } \\ & \text { Minta mengantarkan } \\ & \text { Minta buat } \\ & \text { Minta bikin } \\ & \text { Minta tambah (waktu) } \\ & \text { Minta kasih (tahu) } \\ & \text { Minta ajari } \\ & \text { Minta hari (lain) } \\ \text { Minta }+ \text { Kata Benda } & \text { Minta kesempatan } \\ & \text { Minta keizinan }\end{array}$

Dengan melihat variasi bentuk minta yang dikombinasikan dengan kata lain di atas, dapat ditarik kesimpulan bahwa PBK mengandalkan kata penanda kesantunan minta ini untuk membuat tuturan permintaan. Penggabungan kata minta dengan kata lain memang akan membuat tuturan menjadi lebih santun. Akan tetapi, PBK tidak memperhatikan apakah bentukbentuk yang dihasilkan tersebut lazim digunakan di dalam tuturan bahasa Indonesia. 


\section{3) Pemilihan Kata Penarik Perhatian}

Kata penarik perhatian (attracters) adalah salah satu jenis pembuka tuturan berupa satuan kebahasaan yang berfungsi menarik perhatian dan memberi tanda kepada mitra tutur bahwa dia akan dilibatkan dalam sebuah tindak tutur (Blum-Kulka, 1989). Dalam pemilihan kata-kata ini, ditemukan beberapa perbedaan antara PBK dengan penutur asli bahasa Indonesia. Berikut ini adalah tabel yang merangkum perbedaan pemilihan kata penarik perhatian tersebut.

$\begin{array}{ll}\text { PBK } & \text { Penutur } \\ \text { Hei! } & \text { Hei! } \\ \text { Hai! } & \text { Hai! } \\ \text { Halo! } & -- \\ \text { Halu! } & -- \\ \text { Eh! } & \text { Eh! } \\ \text { Ah! } & -- \\ \text { Wah! } & \text { Wah! } \\ \text { Aduh! } & \text { Aduh! } \\ \text {-- } & \text { Waduh! } \\ \text { Oh, ya! } & -- \\ \text { Gimana, ya! } & -- \\ \text { Oh, my God! } & -- \\ \text { Ano! } & -- \\ \text { Hmm } & \text { Hmm }\end{array}$

\section{4) Pemilihan Kata Perkenalan}

Kata perkenalan yang dimaksud di sini terbagi menjadi dua bagian, yaitu pernyataan identitas diri (self-identity) dan perkenalan diri (self-introduction). Pernyataan identitas diri (self-identity) adalah elemen berupa pernyataan identitas diri yang dinyatakan di dalam sebuah tuturan permintaan. Elemen ini digunakan saat tidak mengenal mitra tutur, penutur akan menanyakan identitas mitra tutur. Sementara itu, perkenalan diri (self-introduction) merupakan elemen yang digunakan saat penutur dan mitra tutur tidak saling mengenal, penutur memperkenalkan dirinya kepada mitra tutur untuk memulai percakapan.

Dalam penggunaan kata perkenalan ini, ada beberapa perbedaan yang ditemukan dalam tuturan meminta yang dihasilkan oleh PBK dengan tuturan meminta yang dihasilkan oleh penutur asli bahasa Indonesia. PBK dan penutur asli bahasa Indonesia memperkenalkan dirinya terlebih dahulu kepada mitra tutur yang status sosialnya lebih tinggi dan tingkat familiaritasnya rendah sebelum menyampaikan permintaannya. Bedanya, PBK memperkenalkan dirinya dengan menyebutkan nama diri dan asal negaranya karena ia adalah mahasiswa asing sedangkan penutur asli hanya menyebutkan nama diri saja.

Perkenalan diri yang dilakukan oleh PBK ini tidak hanya dituturkan pada mitra tutur yang status sosialnya lebih tinggi, tetapi juga kepada mitra tutur yang status sosialnya lebih rendah. PBK juga cenderung menanyakan identitas mitra tutur sebelum melakukan permintaan. Sementara itu, penutur asli tidak memperkenalkan dirinya terlebih dahulu kepada mitra tutur atau menanyakan identitas mitra tutur yang status sosialnya lebih rendah.

\section{d. Perbedaan dalam Pemilihan Pronomina Persona}

Temuan dalam studi ini menunjukkan bahwa PBK cenderung menggunakan pronomina formal dibandingkan pronomina informal. Pronomina formal saya dan anda dipakai pada tuturan terhadap mitra tutur yang memiliki status sosial yang lebih tinggi, setara, atau lebih 
rendah. Walaupun demikian, ditemukan juga penggunaan kata ganti orang informal dalam jumlah yang kecil. Berikut ini adalah tuturan-tuturan permintaan yang membedakan pemilihan pronomina oleh PBK dan penutur asli.

\begin{tabular}{|c|c|}
\hline PBK & Penutur Asli \\
\hline $\begin{array}{l}\text { (53) Halo. Anda pernah lihat saya di dalam } \\
\text { kelas dosen itu? Saya pikir kita mengikuti } \\
\text { kelas yang sama. Sekarang saya harus } \\
\text { menghubungi dosen, tapi nomornya terhapus } \\
\text { dari hape saya. Bisa Anda kasih tahu? }\end{array}$ & $\begin{array}{l}\text { (57) Dik, maaf, ada pena lagi nggak? Kalau } \\
\text { ada saya mau pinjam. } \\
\text { Konteks: Status sosial mitra tutur lebih } \\
\text { rendah daripada penutur, familiaritas rendah. }\end{array}$ \\
\hline
\end{tabular}

(54) Eh, kamu lagi pakai apa? Boleh saya coba? Sebenarnya saya sekarang merasa kulitku kering, perlu lotion.

Konteks: Status sosial mitra tutur dan penutur
setara, familiaritas tinggi.

(55) Permisi, boleh Anda beri tahu alamat ini? Minta tolong.

Konteks: Status sosial mitra tutur dan penutur setara, familiaritas rendah.

(56) Selamat sore Profesor. Nama saya Jooyeon Kim. Sebenarnya saya sangat ingin untuk mengikuti kuliah Kebudayaan Indonesia. Tapi kedengarannya kuota mahasiswa sudah habis. Karena Anda profesor yang mengajar mata kuliah itu, saya meminta Anda membiarkan melebihkan kuota kuliahnya.

Konteks: Status sosial mitra tutur lebih tinggi daripada penutur, familiaritas rendah.

Data set di atas menunjukkan bahwa ada perbedaan dalam penggunaan pronomina dalam tuturan permintaan PBK dan penutur asli bahasa Indonesia. Sudah dijelaskan di atas bahwa PBK cenderung memilih pronomina formal saya dan anda. Pemilihan bentuk tersebut ditemukan pada tuturan meminta pada mitra tutur yang status sosialnya lebih rendah, setara, dan lebih tinggi daripada penutur.

Penyebab perbedaan bentuk tuturan meminta yang dihasilkan oleh PBK dan penutur asli tersebut dibedakan menjadi dua, yaitu penyebab linguistik dan penyebab nonlinguistik. Penyebab linguistik adalah penyebab-penyebab perbedaan yang sumbernya berasal dari bahasa. Penyebab linguistik ini dibedakan lagi menjadi dua, yaitu pengaruh transfer pengetahuan 
pragmatik B1 (Bahasa Korea) dan ketidaksempurnaan kemampuan gramatikal. Sementara itu, penyebab nonlinguistik adalah penyebab-penyebab kesalahan berbahasa yang bukan bersumber dari faktor bahasa, tetapi faktor di luar bahasa. Penyebab nonlinguistik ini meliputi perbedaan budaya, lingkungan pembelajaran bahasa Indonesia, dan kebiasaan menggunakan bentuk tidak formal dalam percakapan.

Salah satu faktor yang sangat berpengaruh terhadap adanya perbedaan dalam tuturan meminta dalam bahasa Indonesia antara PBK dan penutur asli adalah pengetahuan pragmatik dalam bahasa Korea. Salah satu perbedaan tersebut adalah sistem sapaan. Saat menyapa mitra tutur yang status sosialnya lebih tinggi, misalnya profesor, PBK lebih banyak menyapa dengan menyebutkan Profesor, Prof, Dosen atau Guru sedangkan penutur asli menyapa dengan menyebutkan Bapak atau Ibu. Berikut ini adalah tuturan meminta oleh PBK yang masih terpengaruh pengetahuan pragmatik terhadap bahasa Korea.

(61) Guru, saya Jujang dari Korea. Saya mau sit in di kuliah Guru. Minta beri surat izinnya. Minta tolong.

Pada data (61) di atas, ditemukan lagi satu jenis transfer negatif dari sistem sapaan bahasa Korea yang membuat tuturan permintaan PBK dalam bahasa Indonesia menjadi janggal. Selain menggunakan sapaan Guru yang tidak lazim digunakan penutur asli kepada dosennya, PBK juga tidak menggunakan pronomina untuk menggantikan guru pada tuturan tersebut. Penutur asli cenderung akan menuturkan tuturan (61) di atas sebagai berikut.

(61a) Bapak, saya Jujang dari Korea. Saya mau sit in di kuliah Anda. Minta beri surat izinnya. Minta tolong

Pada data (61a) di atas direkonstruksi tuturan dengan sapaan yang lazim digunakan dalam bahasa Indonesia. Penutur asli cenderung akan menggantikan sapaan guru pada data (156) dengan pronomina anda. Hal ini juga berkaitan erat dengan sistem sapaan dalam bahasa Korea. Berikut ini adalah contoh yang lain beserta konstruksi yang tepat dalam bahasa Indonesia.

(62) Pak, saya ada permintaan. Saya mau mendaftarkan program beasiswa. Bolehkah Pak bisa kasih surat rekomendasi kepada saya? Kalau begitu saya akan belajar rajin, Pak.

(62a) Pak, saya ada permintaan. Saya mau mendaftarkan program beasiswa. Bolehkah Bapak bisa kasih surat rekomendasi kepada saya? Kalau begitu saya akan belajar rajin, Pak.

(62b) Pak, saya ada permintaan. Saya mau mendaftarkan program beasiswa. Bolehkah Anda kasih surat rekomendasi kepada saya? Kalau begitu saya akan belajar rajin, Pak.

Pronomina tidak banyak digunakan dalam bahasa Korea daripada di dalam bahasa Inggris (Lee dan Ramsey, 2000:228). Khususnya, pronomina orang ketiga tidak banyak digunakan. Tidak ada peraturan dalam bahasa Korea bahwa kata benda yang telah dimunculkan sebelumnya dalam sebuah tuturan harus digantikan dengan pronomina setelahnya. Untuk memperjelas pembahasan, berikut ini diberikan tuturan dengan kata nuna (kakak perempuan dari seorang laki-laki) yang berulang penggunaannya dalam sebuat tuturan dan tidak dipronominakan (pronominalized). 
누나는 부산에서 태어났다. 누나가 고향인 부산을 떠난 것은 고등학교를 졸업하고서였다. 그 후 누나는 다시는 부산에 가지 못하였다. 그러나 고향을 향한 누나의 애정은 한 시도 식은 적이 없다.

Nuna nun Busan eseo theonatta. Nuna ga gohyangin Busan eul tteonan geoseun godeunghakgyo reul joreobhagoseoyeotta. Geu hu nuna neun dasi neun Busan e gaji mothayeotta. Geureona gohyang eul hyanghan nuna-eui aejeong eul jeoki eopta.

'Kakak perempuan saya lahir di Busan. Kakak perempuan saya meninggalkan rumah kami di Busan selepas lulus dari SMA. Setelah itu, kakak perempuan saya tidak pernah kembali ke Busan. Walaupun demikian, rasa rindu kakak perempuan saya terhadap rumah di kampung halamannya tak pernah hilang.'

Kata kakak perempuan saya berulang dalam bahasa Korea sedangkan dalam bahasa Indonesia kata tersebut lebih lazim digantikan dengan pronomina dia seperti dalam konstruksi berikut.

'Kakak perempuan saya lahir di Busan. Dia meninggalkan rumah kami di Busan selepas lulus dari SMA. Setelah itu, dia tidak pernah kembali ke Busan. Walaupun demikian, rasa rindunya terhadap rumah di kampung halamannya tak pernah hilang.'

Dengan melihat perbedaan sistem pronomina tersebut, dapat diketahui bahwa penyebab perbedaan penggunaan pronomina dalam tuturan permintaan PBK dan penutur asli adalah transfer pengetahuan pragmatik dalam bahasa Korea. Hal ini berkaitan dengan sistem sapaan dalam bahasa Korea dan budaya Korea.

Salah satu penyebab perbedaan tuturan meminta yang dihasilkan oleh PBK dibandingkan dengan penutur asli adalah kebiasaan menggunakan ragam informal. PBK tinggal di kota Yogyakarta. Menurut penelitian terdahulu oleh Primantari (2012:113), dikatakan bahwa setiap hari PBK mendengar adanya variasi bahasa Indonesia yang dituturkan di masyarakat, mulai dari bahasa gaul sampai bahasa Indonesia yang terinferensi bahasa Jawa. Perkenalan mereka dengan penutur asli bahasa Indonesia tentu saja akan menambah kemampuan berbahasa mereka menjadi lebih baik. Akan tetapi, mereka juga akan sering terpapar dan terbiasa mendengarkan penggunaan bahasa yang salah dalam komunikasi sehari-hari atau terbiasa mendengarkan bahasa gaul yang ragamnya informal. Mereka sering mendengarkan bentuk-bentuk bahasa Indonesia informal dan ikut menggunakannya juga tanpa tahu kaidah pembentukannya dan dalam situasi apa bentuk informal tersebut dapat digunakan. Hal ini tercermin dari tuturan meminta yang diproduksi oleh PBK. PBK tidak mengerti kapan dan pada siapa bentuk-bentuk kebahasaan informal tersebut digunakan karena mereka hanya terbiasa mendengar. Bentuk kesalahan yang terpengaruh oleh bentuk informal ini contohnya adalah pelesapan imbuhan, khususnya afiks pada verba, seperti yang sering ditemukan pada penggunaan bahasa informal di masyarakat.

Pembelajar juga mempunyai pemikiran bahwa jika ia menggunakan bahasa gaul, dia akan terlihat keren di mata teman-temannya. Penggunaan bentuk informal tersebut tidak ada salahnya jika digunakan pada tempatnya. Masalahnya, karena terbiasa menggunakan bentuk-bentuk informal tersebut, pembelajar menggunakan bentuk tersebut hampir pada semua situasi dan semua mitra tutur, tidak peduli mitra tutur memiliki status sosial yang lebih tinggi.Pembelajar menganggap kemampuannya dalam menggunakan ragam informal merupakan 'kemajuan' dalam belajar bahasa Indonesia, hal yang belum bisa dikuasai oleh teman-teman sekelasnya 
yang lain. Berikut ini adalah tuturan permintaan yang mengandung ketidaktepatan disebabkan kebiasaan penggunaan bentuk informal.

(63) Pak, aku pengen belajar, minta bikin surat rekomendasi.

(64) Boleh pertanya? Aku orang asing kasihan tersesat, tolong antarin kos teman aku.

(65) Pak, aku berminat sekali kuliah pak. Pak adalah salah satu prof yang paling bagus di dunia ini. Aku boleh ikut nggak? Cuma sit-in aja.

Tuturan-tuturan permintaan di atas adalah tuturan dari seorang PBK yang menganggap bahwa penggunaan ragam bahasa informal adalah tanda penguasaan bahasa Indonesia. Akibatnya, PBK menggunakan berbagai bentuk informal saat menyusun tuturan permintaan. Bentuk informal tersebut dapat dilihat pada pemilihan kata kerja pengen dan bikin pada data (63), pemilihan pronomina $a k u$ dan kata kerja tidak baku antarin pada data (64), dan pronomina aku dan kata cuma pada data (65). Ketiga tuturan tersebut menuntut pemilihan ragam tuturan formal karena dituturkan kepada mitra tutur yang lebih tinggi status sosialnya daripada penutur. Oleh karena itu, pemilihan ragam informal berupa penggunaan bentuk-bentuk tidak baku membuat tuturan menurun derajat kesantunannya.

\section{KESIMPULAN}

Secara garis besar, penyebab penyimpangan TTM berbahasa Indonesia yang dilakukan oleh PBK terjadi karena faktor linguistik dan faktor nonlinguistik. Penyebab linguistik yang ditemukan adalah pengaruh transfer pengetahuan pragmatik B1 (Bahasa Korea) dan ketidaksempurnaan kemampuan gramatikal sedangkan penyebab nonlinguistiknya meliputi perbedaan budaya, lingkungan pembelajaran bahasa Indonesia, dan kebiasaan menggunakan bentuk tidak formal dalam percakapan. Ketidaksempurnaan kemampuan gramatikal dan transfer negatif B1 (Bahasa Korea) menjadi penyebab utama terjadinya penyimpangan dalam pemroduksian TTM.

\section{DAFTAR PUSTAKA}

Achiba, Machiko. 2003. Learning to Request in a Second Language. Clevedan: Multilingual Matters.

Blum-Kulka, Shoshana, Juliane House, dan Gabriele Kasper. 1987. Cross-cultural Pragmatics: Request and Apologies. New Jersey: Ablex Publishing Corporation.

Blum-Kulka, Shoshana dan Gabriele Kasper. 1993. Interlanguage Pragmatics. Oxford: Oxford University Press.

Brown, Penelope and Stephen Levinson. 1987. Politeness: Some Universals in Language Usage. Cambridge: Cambridge University Press.

Lee, Iksop dan Robert Ramsey. 2000. The Korean Language. Albany: State University of New York.

Nadar, Franciscus Xaverius. 2006. "Penolakan dalam Bahasa Inggris dan Bahasa Indonesia: Kajian Pragmatik tentang Realisasi Strategi Kesopanan Berbahasa”. Disertasi. Fakultas Ilmu Budaya Universitas Gadjah Mada.

Park, J. 2001. “Korean EFL Learners' Politeness Strategies in Their Complaints” dalam The 
Lingustic Association of Korea Journal, 9 (1) halaman 185-209.

Pateda, Mansoer. 1989. Analisis Kesalahan. Flores: Nusa Indah.Pratita, Ina Ika. 1999. “Tindak Tutur Permintaan dalam Bahasa Indonesia: Studi Kasus Tindak Tutur pada Ranah Keluarga di Surabaya”. Tesis. Tidak Diterbitkan. Yogyakarta: Universitas Gadjah Mada

Primantari, Adista Nur. 2012. “Analisis Kesalahan Berbahasa Indonesia pada Tataran Sintaksis oleh Pembelajar BIPA dari Korea”. Skripsi. Tidak Diterbitkan. Jurusan Sastra Indonesia, Fakultas Ilmu Budaya, Universitas Gadjah Mada Yogyakarta.

Rahardi, Kunjana Remigius. 1999. "Imperatif dalam Bahasa Indonesia: Kajian Pragmatik tentang Kesantunan Berbahasa”. Disertasi. Tidak Diterbitkan. Universitas Gadjah Mada Yogyakarta.

Sukamto, Katharina Endriati. 2012. "Polite Request by Korean Learnes of Indonesian" dalam Studies in Literature and Language Vol. 5, No. 2, Hal. 1-9. Canadian Academy of Oriental and Occidental Culture.

Wierzbicka, Anna. 1991. Cross-cultural Pragmatics. Berlin: Moyton de Gruyter. Wijana, I Dewa Putu. 1996. Dasar-dasar Pragmatik. Yogyakarta: Andi.

Yule, George. 1996. Pragmatik. Yogyakarta: Pustaka Pelajar.

Zubaidi, Nanang. 2013. "Realisasi Keluhan oleh Pembelajar Asing Bahasa Indonesia: Kajian Pragmatik Bahasa Antara (Interlanguage Pragmatics)". Tesis. Program Pascasarjana Program Studi Linguistik Fakultas Ilmu Budaya Universitas Gadjah Mada Yogyakarta. 